\title{
視覚的補助による韻律指導法の紹介と提案 \\ An Introductory Proposition to Teaching Methods of Prosody with Visual Aids
}

\author{
中川 千惠子 \\ 早稲田大学日本語教育研究センター \\ 中村 則子 \\ 東京外国語大学留学生日本語教育センター
}

\section{1 はじめに}

そもそも発音を勉強する必要があるのだろうか。通じることが重要であって、話し手も聞き手もお互いに理解し合 おうとする態度が大切だ、発音のようなことを考える必要はないという考え方もある。その一方で、学習者のスピーチ を聞いていて、途中までなんの話か分からなかったなどといらような経験を持ち、そうした学習者の発音をなんとか したいと考える教師も多くいる。また、学習者自身も、学習が進んでくると、自分の発音をなんとかしたいと考えること が少なくない。本稿では、発音指導や学習そのものについて考え、筆者らが考える指導法「フレージング指導法」を 紹介したい。

\section{2 発音を指導する·学習するとは}

母語話者は総合的に holistic に言語を習得すると言われる。しかし、Ioup \& Tansomboon(1987)が言うように、学習 者の場合、総合的(holistic)なアプローチができるのは、学習成功者(good learner)だけであって、通常は、分析的に ストラテジーを指導する必要があると考えられる。日本語を学習する際、文法や漢字は必要な要素であるが、発音 はどちらかと言うと不必要な要素であるとは言われることが多い。しかし、音声も文法も語彙もそれぞれ言語活動の 重要な役割を担う。文法を学ぶのが大切だとすれば、発音を学ぶのも大切である。

コミュニケーションは話し手だけでは成り立たない。まず、聞き手のことを考えてみよう。発話では、まず、耳に音 声が届く、それが聞きにくかったり、分かりにくかったりするとしたらコミュニケーションの障害となる。また、なんとか 分かっても、分かりにくい発音が聞き手の話し手に対する印象を悪くしてしまうという事実を止めることはできない。 聞き手自身が何も言わなかったとしても許容の限界がある。

次に、話し手について考えてみよう。スピーチを格好良く決めてみたい、あるいは、きれいな発音で話したいとい う学習者がいる。こ考える学習者の考えが間違っていると言えるだろうか。そうした学習者自身の自己実現の欲求 を阻む権利が教師にあるとは思えない。むしろ教師はそうした学習者の欲求を支援できる準備を整えていたい。もう ひとつ考えられるのは、どんなときに発音が問題になるかである。場面によってどんな発音が要求されるかは異なる だろう(国際交流基金 2009)。買い物や簡単な会話では、分かればよいといらことであまり発音が気にならなくても、 


\section{中川 千惠子、中村 則子: 視覚的補助による韻律指導法の紹介と提案}

研究発表やなにか売り込みのプレゼンを寸る場合は、分かりやすく聞きやすい発音であるほうがよい。

発音の指導法は、それほど多いとは言えない。また、その数少ない指導法のうち一つの指導法がどんな学習者 にも向いていることもない。学習者のニーズや学習環境によって、到達目標や学習時間などが異なるし、学習者自 身の特性によっても異なる。学習者の性格や信念の影響もあるだろう。学習者の到達レベルによっても学習スタイル や学習ストラテジーや動機が異なるといら知見もある(中川・シェパード・木下2008)。教師の側も同様である。教師が ネーティブかノ・ネーティブかも大いに影響するだろう。教師の性格や信念も関係する。学習者の特性と教師の特 性が相互作用して教室活動は進められる。学習者にとって学習可能(learnable)であると同時に、教師にとつて指導 可能(teachable)であり、さらに、使用可能(usable)であるというも観点から指導法を考えたい(Taylor1996)。

音声指導といらと、入門期の「あいうえお」で単音の指導に終わることが多く、もつと大きい単位である拍を基本とす るリズムやアクセントやイントネションの指導を受ける学習者は少ない。中川・中村·許(2009) は、そうした中上級 の学習者を対象にしたイントネーションに焦点を置いた指導法「フレージング練習法」を開発し、聞きやすく分かりや すい発話を目指して指導を行ってきた。当初は、発音に注意を向けて話すためには、ある程度日本語の学習が進 んでからのほうがいいだろうと考えており、中級以上の学生対象のテキストを作成したわけである。しかし、試みに 初級で視覚的補助を用いた韻律指導を実践してみたところ、入門期、初級でも十分可能であることがわかった。現 在は、むしろ、初級、あるいは入門から意識的に導入すべきではないかと考えている。本稿では、入門期や初級学 習者を対象とした発音指導法について提案するが、その前に、中上級用に開発した「フレージング練習法」の根拠、 具体的方法を述べたい $(1)$

\section{3 フレ一ジング練習法とは}

\section{1 なぜイントネーションに焦点をおくか}

筆者を含めて、日本人が外国語を話すときを考えてみよう。/r/と/1/の発音は日本人にとって苦手な発音である。 単音の発音といらのは、聞いて分からなくても調音点や調音法に注意寸ればなんとか発音できる場合が多い。しか し、常に自信を持って発音できるとは限らない。実際、筆者がフランスに滞在したとき、チーズ屋さんに行って、 “fromage blanc”(フロマージュ・ブラン:ナチュラルチーズの一種) と言ったつもりなのに、発音が悪くて伝わらなかっ たことがある。その次のとき、“Je voudrais du fromage blanc.”(フロマージュ・ブランください)といら文で言ってみたと ころ、分かってもらえてほっとしたという経験がある。佐藤(1995)は、聴取実験を行った結果、高さ・長さ·強さでは、高 さの影響力がもつとも大きく、単音と韻律(プロソディー)では、韻律が評価に影響すると報告している。短い単語で あれば聞き手は単音に注意を払うが、文になると、文全体のイントネーションに注目するから、“Je voudrais du fromage blanc.”のほうが、“fromage blanc”より分かりやすかったと言えそうである。また、単音発音は改善が困難であ り、発音が苦手になる原因の一つであるのに対して、アクセントやイントネーション、ポーズは、直しやすい。特にポ ーズは、気をつけさえすれば、すぐに直せるものである。更に、様々な母語の学習者が混在しているクラス内にお

\section{特別寄稿}


いて、単音は、母語の違いにより、問題であったりなかったりするので扱いにくいが、アクセント・イントネーションの 誤りは、誤りの姿はそれぞれ異なっても、問題であることは共通しているので、クラス授業で教えやすい。

\section{2 フレージングの根拠}

次の図1は日本人が発話した録音音声から声の高低であるピッチカーブを抽出したものである(2)。

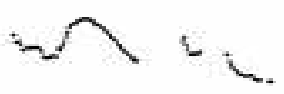

にぼんにきてから

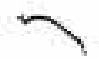

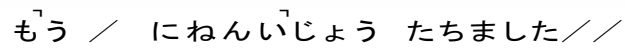

\section{図1:ピツチカーブ}

図1の特徴をあげてみる。この文は間にポーズが入った 3 つの山から成る。これは音調句またはフレーズと呼ば れるものである。川上(1961)によると、「句」は間に句切りを入れずにひとまとまりで発音された音調単位であり、「句 切り」は音調的切れ目である。また、 1 個の句は、数個または 1 個の単語から成り、 1 個の文は数個または 1 個の句 から成っていて、句切りは必ずしも呼気の停止(ポーズ)をともなわないと言う(3)。句(フレーズ)は句頭でピッチが上昇 し、アクセント核で下降する。つまり山の形は、句の長さとアクセント核の位置による。来て」や「ました」はアクセント 核があるのだが、句内の最初のアクセント核の後ろにあるアクセント核は低く抑えられている。この階段のように下が っていく「ダウンステップ」といら現象が、日本語のイントネーションが「へ」の字になるための大事な要素だと言える だろう。この図を見ながら発音すれば、日本人の発話に似るはずだが、このピッチカーブの抽出は、録音音声の音 質がよいという条件の他に、抽出しても操作が必要であること、[k][s]など無声子音で断絶があって見にくいなど、実 用的ではないため、図2のように手描きで書くほうが実用的である。

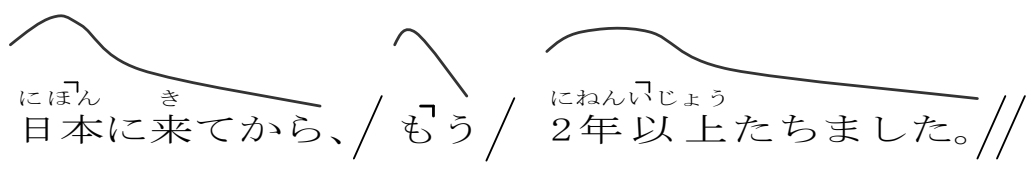

図2:手描きピッチカ一ブ

この図2は、ソフトで抽出しなくても描ける。中上級レベルの学習者であれば、「句切り」を入れ、「ピッチカーブ」、 「アクセント核」をつけることができるようになる。これを「フレージングする」と呼び、学習者自身がフレージングして 読み上げる練習をする。これによって、指導が終わってからも自分でできるようにするのが目的である。 


\section{3 学習スタイルとの関係}

「フレージング練習法」は、視覚的な補助を使用しているが、こうした視覚的表示がすべての学習者に適している とは言えない。中川・シェパード・木下(2008)では、日本人に近い発音をする学習成功者 (good learner と呼ぶ) とそ れ以外の学習者(average learner と呼ぶ)の学習者が学習するときに好む、あるいは習慣的に選如ている知覚学 習スタイルについて調查した。その結果、質問紙における意識調查結果とフレージングタスク直後の再生刺激法イ ンタビューにおける分析結果が類似した傾向を示していた。good learner は聴覚型を強く選如, 視覚型の学習スタ イルではないのに対し、average learner は聴覚型や視覚型、触覚型といら様々な学習スタイルが認められた。つまり、 average learner は様々な道具を駆使するようである。 good learner はフィードバックを聞いてタスクを修正できるが、 average learner は聞いただけでは修正できない場合がある。すなわち、 average learner は、フィードバック時に修正 できなくても、フィードバックをあとで視覚的に確認できるような方法が必要であり、そのために記録しして、ピッチカ ーブなどのマークが役に立つと考えられる。

\section{4 フレージングの手順}

フレージングの手順を具体的に示す。

\section{（1）句切りを入れる}

まず、音声を聞いて、あるいは聞かずに内省で、図3のような句切りを入れる。音声的な句切りは、図1に見られる ように、明らかな息継ぎのポーズが生じる場合もあるが、ない場合もある。この句切りと句切りの間の一つひとつの山 を「フレーズ」と呼ぶ。フレーズの終わりは声が下がっていて、フレーズの始まりには声の立ち上がり、つまり、句頭 の上昇があるから、「へ」の字になるのだといらことを念頭に置く。なお、眓3では、ひらがなで示しており、ひらがな は1拍ごとの拍間隔を養うには良い。しかし、読みにくいので漢字にルビを振ったものを実際には使用するのがい いだろう。フレーズの長さは短いとアクセントに焦点が置かれすぎるが、長すぎても、「へ」の字に声をコントロールし て下げていくのが難しいので、長くても 15 拍ぐらいまでとする。日本語レベルによってもフレーズの長さは異なるだ ろう。初級であるほど学習者の話寸速さが遅いので、初級の場合は、各フレーズの長さをあまり長くしないほうがよ いであろう。

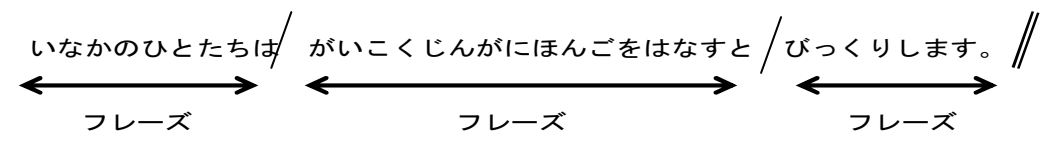

\section{図3: 句切りを入れる}

\section{特別寄稿}




\section{(2)ピツチカーブを描く}

図4のように、声の上がり下がりを表すピッチカーブを描く。意味の句切りが入っていて、「へ」の字型イントネーショ ンが描けていれば第1段階ししては十分である。

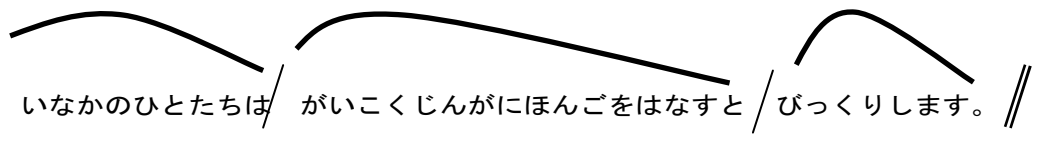

図4:ピツチカーブを描く

\section{（3）アクセント核のマークを付ける}

より正確なイントネーションのためには、アクセント核を付ける。確信が持てないときはアクセント辞典を使用したり して、図5のように、アクセント核を付ける。

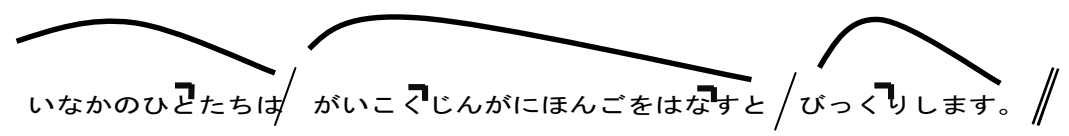

\section{図5:アクセント核を付ける}

1フレーズ内にアクセント核が複数個ある場合でも、フレーズの最初のアクセント核のみ付けて、「へ」の字を描い ていればよいとして、フレーズ内の2番目以降のアクセント核(図5では「はなす」の「な」のアクセント)は義務ししな い。通常(強調などがない場合)、フレーズ内の最初のアクセントの下がりが一番大きく、後のアクセント核は、アクセ ント弱化により目立たなくなっているので、2 番目以降のアクセントを気にするより、自然に下降寸ればいいとする。 実現すべきアクセント核の数を減らすことで、学習者の負担を減らすことにもなる。とくに、中国語母語話者の場合、 ピッチの上下に敏感であるため、アクセントに注目しすぎて、2 番目、3 番目のアクセントが弱化しない傾向がある。 その結果、フレーズの山がたくさんあるように聞こえ、「へ」の字型イントネーションが実現されない不自然な発音に なってしまうので、アクセントは最初のものだけでいいといら指導は効果的である。

\section{4 初級レベル学習者のためのフレ一ジング練習}

中上級用の指導法の一部を利用して、入門期、初級の韻律指導を行うことができる。入門期や初級レベルでは、 自分でフレージングマークを描かなくても、マークを見て声の上げ下げに気をつけて発音寸れば、十分である。発 音をことさら取り出して指導したり練習したり寸るのではなくて、日常の学習の中に組み込んで行くようにしたいもの 
である。完璧な発音でなくとも、意識しながら練習寸ることが重要であろう。目標は、適切なところでゆっくり句切るこ と、そして、「へ」の字にすることであり、アクセントについては、可能であれば学習することにしたい。

以下に、初級クラスのための発音教材の一部を紹介して、指導方法を提案する。本テキストは、文型練習、会話練 習、スピーチ活動などから構成され、文型の口慣らしとしての口頭練習を、発音を意識させながら行い、文型の定着 とともに、発話の自然さ、聞きやすさの向上を目指す ${ }^{(4)}$ 。

\section{1 入門期の指導法}

以下に入門初日の自己紹介例を挙げる。

\section{入門初日例(板書)}

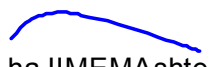

haJIMEMAshte

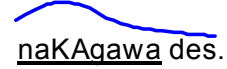

YoKOHAMA KARA kiMAshta.

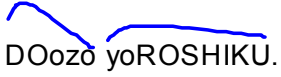

部分的に消した板書例

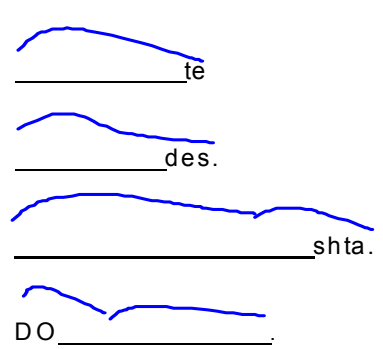

ここではローマ字を使用した例を示した。下線部に自分の名前や出身地を入れて、これを十分練習した後、部分 的に消して、ピッチカーブを見ながら言わせる。

ローマ字表示は長所短所もあるだろう。長所ししては、大文字と小文字を使い分けられるので、低い音は小文字、 高い音は大文字にして、ひと目でアクセントが分かるように示寸ことができる。また、無声子音の間にある[u]や[i]は 無声化することが多いので、shiをshのように記すことができ、ひらがなより分かりやすい。その他に、長音などの特 殊拍についても、ほぼ発音通りに表示しているため、ひらながのように、文字と発音とのギャップがない。しかし、短 所としては、アルフアベットが、ある言語では日本語とは違読み方をするため、却って混乱を招くこどある。例え ば、ローマ字表記でラ行」は ra,ri,ru,re,ro と記されるが、英語に慣れた学習者は、歯茎はじき暗[rではなく、歯茎接

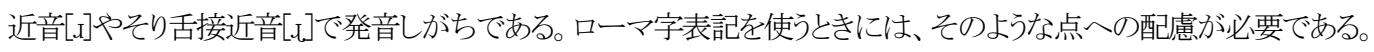

\section{2 初級学習者の指導例}

\subsection{1 会話練習例}

入門期のローマ字表記の後、ローマ字とひらがな併用を経て、漢字仮名交じり文に移行していく。次に挙げる会 話練習例は、ローマ字、ひらがな併用の例である。この課の目標は、「れ、それ、あれ、どれ」のアクセントの意識 
化である。この会話練習の前にまず、「これ、それ、あれ」は平板型なので平らに、「どれ」は疑問詞なので頭高型に 発音するという練習を行う。その後、会話文の中で、自然に発音できるように練習寸る。その際、実物を使い、臨場 感を持たせた上で、「発音にも」気をつけて会話練習を行う。このような練習を通して、文型、語彙の定着とともに、普 段から発音に気をつけて話すといら習慣を身につけさせることができる。

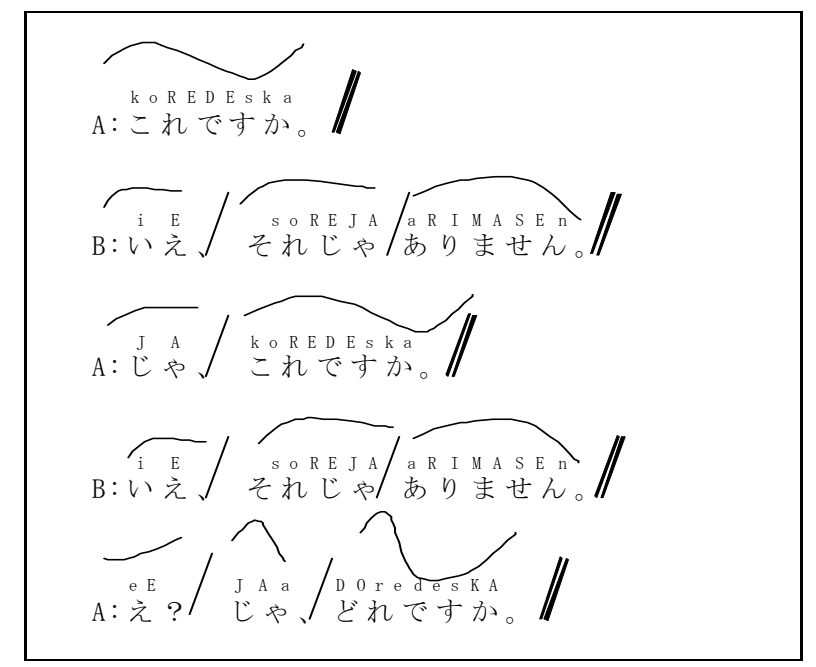

\subsection{2 スピ一千練習例}

世界大統領になったら

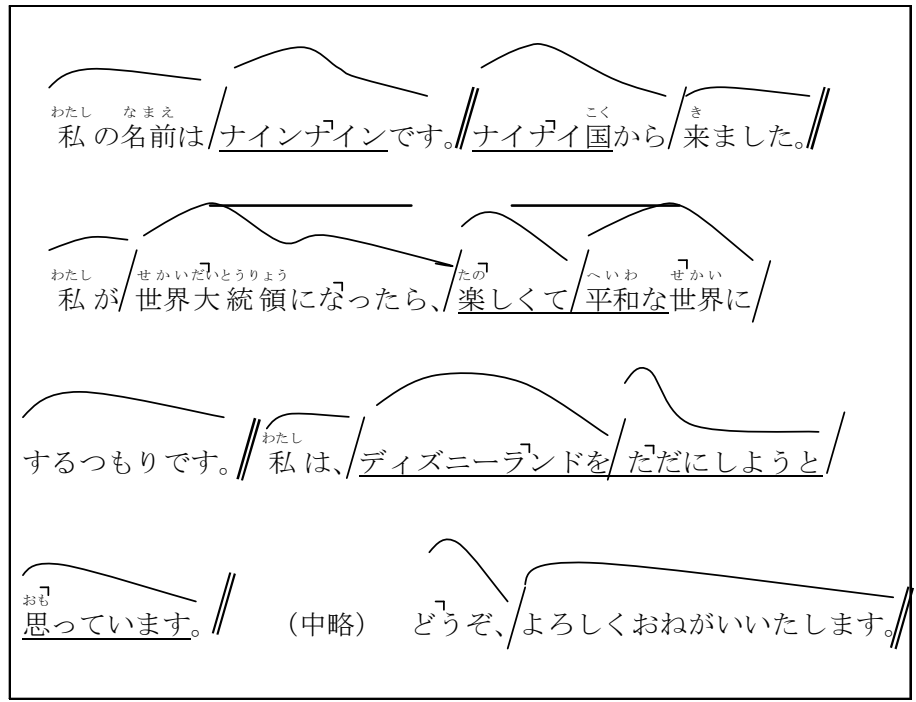




\section{中川 千惠子、中村 則子: 視覚的補助による韻律指導法の紹介と提案}

かなり上級レベルの学習者でも、スピーチなどのまとまった発話では、アクセントやイントネーションで不自然さが 目立ったり寸ることがある。会話では、それほじ気にならなくても、多数の聞き手が耳を澄まして聴いている場合は 目立つのかもしれない。初級レベルでも、短い会話文の練習以外にもこのようなスピーチ練習を設け、発音に留意 しながら発表することに慣れさせたい。ここでは、初級半ばの文型「ようと思っています」「つもりです」の文型定着の ためのスピーチ活動を紹介寸る。この活動は、クラスをグループに分け、各グループで国を作り、世界大統領選挙 に立候補した際のスピーチを行うといらものである。

\subsection{3 練習のやり方}

まず、CDのモデル音声を聞いてから、テキストのマークを見ながら声を出してリピート練習を 1 ，2回行う。それか ら、テキストを閉じてシャドーイング練習をする。シャドーイング練習はやり方が様々であるが(戸田 2009)、ここでは、 文を文字とマークで確認した後に、文字を見ずに、音声が流れてから 2,3 拍(0.5 秒)ほど遅れて発音する方法を提 案する。CDの音声は基本的には、途中で止めなくても構わない。学習者は聞こえたそばから、すぐにシャドーイン グしてい。全体で声を出して繰り返すのは少なくても 3 回から 5 回は行いたいが、学習者の様子を見ながら進める 必要がある。学習者が多い教室では、自分の声が聞こえなくなる恐れがあるので、自室での予習や復習を進める際 に行うよう指導してもよいだろう。なお、学習者が文字を見たほうが安心できるといらなら見ながらでも構わない。

このようにして、モデル文の発音練習が終わったら、各グループでモデル文の下線部を入れ替え、スピーチ原稿 を作成し、更にグループで発音練習を行う。ここでのポイントは、句切りでゆっくり休んでいるか、フレーズが「へ」の 字になっているかである。その 2 点に気をつけながら、グループで十分練習した後、代表を決め、全グループが選 挙演説を行ってから、選挙で大統領を選ぶといった活動が考えられる。

以上、会話練習や活動の中に発音学習を取り入れる方法を紹介したが、工夫次第で様々なやり方ができるだろう。 楽しみながら、意識的に練習が行えるようにしたい。

\section{3 指導上の留意点}

学生たちは、はじめのうち、マークに戸惑ったり、抵抗を示したりするかもしれない。しかし、この抵抗は学習者側 からといらより教師側のものかもしれない。教師が納得できて続ける気があれば、学習者も慣れるだろう。諦めずに 続けることが最も良い方法である。

もう1つの問題は、教師自身の問題である。アクセントに自信がない、あるいは、一応発音できていてもアクセント 記号を付ける自信はないといらような場合である。自信を持ってアクセント記号をつけられる教師は少ないとも言える。 加えて、アクセントには摇れがあって、必ずしもアクセント辞典通りではない発音が普通に使われていることもある。 そうしたことから自分の発音に自信が持てず、苦手意識を持つ教師も多、。苦労してアクセント記号を付けるより、句 切りを付けること、フレーズを「へ」の字にすることだけに止めるのでよいのではないだろうか。アクセント核が含まれ 
ないフレーズの場合は、「山」でなく平たい「丘」のようにと指示寸れば更によいが、句切り部分、特に、句点の後で、 「イチ、ニ」とゆっくり数えるように指導するだけで、スピーチはずっと聞きやすくなる。ネーティブであればアクセント は自然に発音して聞かせるだけで、あとは学習者自身に任せればよい。教師自身の努力も必要だが、教師自身が できること、指導可能であることを行い続けるといら心構えが大事である。

\section{4 母語による注意点}

3.4 でも述べたように、中国語母語話者の場合、四声というものがあるためか、ピッチ変化に敏感である。日本語 のイントネーションにおいて、アクセントが重要であるのは確かなのだが、強調しすぎて、アクセント弱化すべきとこ ろを弱化せずに同じ高さとなってしまうことがある。その結果、句切りが多く、プツンプツンを途切れたような話し方、 あるいは強調が多い話し方に聞こえる。また、生成すべきアクセントが多いと、誤りも多くなってしまう可能性がある。 フレーズの中で注目すべきアクセントは 1 か所であり、それ以降の部分は自然に下がるように指導する。

他の母語話者、たとえば韓国語母語話者の場合は、イントネーション全体が平坦になることが多いので、句頭の上 昇を意識して上昇させ、句末、文末を弱めて下げることで「へ」の字にするように指導する。

こうした問題点は各母語話者特有のものとも言えるが、すべての学習者に共通する問題もある。フレーズ末、文末 で下げるためには、句頭で上昇しなければ、下げられない。句頭の上昇と句末下降があって「へ」の字になるので ある。アクセントの下がりだけでなく、1 拍目から 2 拍目にかけてピッチが上昇する句頭の上昇が、自然なイントネー ションには不可欠なのである。そして、なによりもアクセントやイントネーションの意識化が重要である。常に教師と学 習者自身がプロソディーの重要性を意識していない限り学習は進まない。

\section{5 終わりに}

初めに述べたように、学習者は多様である。学習者が百人いれば百通りの学習方法が必要だろう。知覚学習ス夕 イルも聴覚型(耳型)学習者もいれば視覚型(目型)学習者もいる。身体を使いたい学習者もいるだろう。学習者自身 が自分の学習のために自分で選択寸るのが望ましい。また、同じ学習者であっても学習段階や、学習環境に応じて 道具を変えることもある。できるだけ多くの選択肢があったほうがいいだろう。さらに多くの指導法の開発が待たれ る。

本稿で述べた句切り、アクセント核、ピッチカーブなどフレージングマークも、学習者の可能性を広げる道具の一 つである。日本人であっても客観的に学習者の発音について指摘することは難しいが、直感的に「おかいいり感じ て、そう言うことはできる。学習者は日本人に「おかしいと言われたら自分で分析し、自分で考えて修正できる能力 を身につける必要がある。フレージングマークは、このような「自律学習」の助けにもなると考えられる。

言語学習に共通の目標は、他者と伝え合って、よりよい関係を持つことであるが、発音学習も同様である。クラス内 の学習者同士および教師は、自分の気持ちや考えを伝えようとするが、その際、発音がわかりやすければ、相手は 
その発話をしっかり受け止め、また投げ返すことができる。学習プロセスにおけるそのような行為そのものが発音学 習の重要な目標となっていると言えるだろう。

100\%正確な発音といらものはない。発音は多様であり、動的なものである。自分の発音に自信のある教師も、モ デル音声、テキスト、他の日本人の発音と自分の発音が異なる場合は、共に考えてほしい。また、自分の発音に自 信がない教師の場合は、教室を学習者と共に学ぶ「協働学習」の場しして捉えてもよいのではないか。そうした共に 考える場を提供し支援するのが、教師の役割であり、必ずしも、教師がすべてを教える必要はない。教育の場を「共 育」の空間とすることが可能であろう。

発音学習には、時間がかかる。すぐに効果が見えないので、諦めてしまう教師も多いだろう。しかし、表面に成果 が現れなくても、学習者を励まし、進歩を信じて、そのプロセスを共に楽しむ気持ちを持ちたいものである。

\section{注}

（1）中上級学習者対象テキストである『さらに進んだスピーチ・プレゼンのための発音練習帳』(中川・中村·許 2009) では、学習者が第 1 部の基礎編で「フレージング方法」や複合語、動詞、形容詞、外来語などのアクセント規則学習 をしたのち、第 2 部の応用編で長文フレージング練習を行う。第 2 部では、自分でフレージングマークをつけるか、 解答として掲載されているフレージングモデルを見ながら練習してもよい。付録の簡単辞書(アクセント辞典)にアク セント辞典では調べにくい動詞・形容詞の活用アクセント、名前・助数詞のアクセント表が載っている。ここでは簡単 に理論的な根拠について述べるが、詳しくは、中川(2001a、2001b)を参照されたい。

（2）ピッチ曲線の抽出は、音声分析ソフト SIL Speech Analyzer Version 2.6を使用した。

（3）「句切り」は、「区切り」や「区切れ」と呼ばれることの多いが、本稿および「フレージング指導法」では、「句切り」を 使用する。

（4）早稲田大学におけるコースで、2009 年 4 月から本論文に紹介した内容が入ったテキストを使用し始めた。授業 中の学習者の反応や使い勝手を考慮した上で、加筆修正したものが、2010 年 3 月末に出版される(中村・中川 2010)。CD 音声に現役大学生の声を採用することで、より自然な音声を学習者が学べるようになっている。

\section{謝辞}

本稿は、香港日本語教育研究会定例会における発表をまとめて加筆したものです。発表時にみなさまからいた だいた温かいコメント、城市大学で行った模擬授業における学生および教員のみなさまとの交流によって理解でき たことも多々あります。高橋多教授をはじめ香港の皆さまのご尽力とご協力に深く感謝いたします。

\section{特別寄稿}




\section{参考文献}

川上䔉 (1961)「ことばの切れ目と音調」『國學院雑誌』16、國學院大学 25-46.

国際交流基金(2009)『音声を教える』ひつじ書房

佐藤友則 (1995)「単音と韻律が日本語音声の評価に与える影響力の比較」国際交流基金日本語国際センター 『世界の日本語教育』第5号 139-154.

戸田貴子(2009)「日本語教育における学習者音声の研究と音声教育実践』曰日本語教育』142 号

日本語教育学会 $47-57$.

中川千恵子(2001a)『日本語学習者のプロソディー習得とその指導法』お茶の水女子大学博士論文

中川千恵子 (2001b)「「へ」字型イントネーションに注目したプロソディー指導の試み」『日本語教育』110 号

日本語教育学会 140-149.

中川千恵子・シェパード,C・木下直子(2008)「発音学習における学習成功者と学習遅滞者の学習

スタイルと学習ストラテジーの違い「日本語教育学会秋季大会予稿集』日本語教育学会 146-151.

中川千恵子・中村則子·許舜貞 (2009)『さらに進んだスピーチ・プレゼンのための発音練習帳』ひづ書房 中村則子・中川千恵子(2010)『初級文型でできる にほんご発音アクティビティ』(印刷中)アスク出版 Ioup, G. \& A. Tansomboon (1987) The acquisition of tone: a maturational perspective. In G. Ioup, and S.

Weinberger, (eds.) Interlanguage Phonology. (pp. 333-347), Cambridge, MA: Newbury House.

Taylor, D.S. (1993) Intonation and accent in English: What teachers need to know. International Review of Applied Linguistics in Language Teaching, 1-21. 